\title{
त्री \\ Riscophrenia and "animal spirits": clarifying the notions of risk and uncertainty in environmental problems
}

\author{
Helena Mateus Jerónimo
}

\begin{abstract}
电
ABSTRACT

This article seeks to clarify the concepts of risk and uncertainty, restricting its focus to environmental problems and to three strands of reflection. Firstly, I suggest that we should apply the label riscophrenia to the tendency to envisage most environmental problems excessively in terms of probabilistic risk, erecting the concept to a core dogma of certainty based on the image it offers of (alleged) safety and control of the random. Looking at the most serious environmental problems of the twenty-first century through the prism of "animal spirits" is above all an exercise which shows that unpredictability and uncertainties are constituent elements of human existence and social life. Secondly, I argue that the assessment of uncertainty has political and normative implications. I hold that uncertainty may make it possible to invoke precautionary, not just preventive, measures, and that alternative "contextualised" research strategies, open to a variety of points of view, are possible. Lastly, I claim that the language of risk and its excessive application is generally laden with a type of ambiguity which tends not to emphasize society's current problems, and so facilitates the continuation rather than the questioning of our society's dominant technocratic and technological model.
\end{abstract}

KEYwords • Risk. Riscophrenia. Uncertainties. “Animal spirits”. Environment.

\section{INTRODUCTION}

Modernity's claims to be able to tame uncertainty, which some thought could be realized through the achievements of science, statistics and probability, ${ }^{1}$ have turned out to be a failure. All aspects of individual and collective life are in the final analysis permeated with random elements which cannot be controlled in a rational manner. The notion of control and the rejection of contingencies continue to exist, but they are contradicted by the need to acknowledge not only that uncertainties have not gone away,

1 On the emergence of statistical reasoning and probability, see Hacking (1975; 1990), Porter (1986), Krüger et al. (1987) and Cohen (2005). 
but also by a widespread perception that in a complex and increasingly interdependent world they have returned in strength. Unpredictability is the hallmark of many of the problems we face in the twenty-first century, engendered or influenced by human action often associated with technological and technocratic choices. The common element in these problems is the potentially irreversible nature of the synergistic and trans-generational consequences and effects of technological decisions.

The attempt to control uncertainty was reflected above all in the introduction of the idea of measurable, calculable risk which could be subjected to the utilitarian logic of cost-benefit analysis, so characteristic of the modern cultural context. Although the origins of the idea of risk lie in the daring undertakings of maritime trade and in external factors that might jeopardize any voyage, ${ }^{2}$ such as storms and pirate attacks, it subsequently came to be associated with voluntary decision-making based on potential gains and losses, and the magnitude of the consequences of that decision-making. The act of interpreting the world in terms of risk supposedly made it more understandable, freed it from the powers of mystery, and made it immune to the capriciousness of the gods and the inexorability of destiny. Even if the concept of risk involved acknowledging uncertainty, that uncertainty could be tamed by forecasts and by scientific and technological control. Against this conception, the notion of risk is in fact a secularized version of the goddess Fortuna, who was venerated in antiquity and personified chance and randomness (cf. García, 2006) although, given the probabilistic basis for the use of the concept, it cannot account for complex problems such as the environmental, which may include global warming, biodiversity loss, chemical contaminants, and genetically engineered food crops, amongst others.

This article seeks to clarify the concepts of risk and uncertainty, restricting its focus to environmental problems. This approach is justified by the fact that among the many areas in which the concept of risk predominates, the environment is the one which features radically uncertain phenomena which generate unimaginably complex systems. It is worth stressing that the majority of environmental problems are the result of the unforeseeable effects of technological innovation, encouraged by humanity's desire to control, tame and exploit nature. However, this does not mean that all technologies are harmful to the environment, and there may well be environmental problems which derive from the intrinsic randomness of the natural world. In developing this article I begin by suggesting that we should apply the label riscophrenia to the tendency to envisage most environmental problems excessively in terms of probabilistic

2 Although the origin of the term risk is relatively unknown and thus controversial, most commentators associate it with the language of maritime trade and insurance (cf. Luhmann 1993 [1991]; Lupton, 1999; Martínez, 1999; Strydom, 2002). 
risk, erecting the concept to a core dogma of certainty based on the image it offers of (alleged) safety and control of the random. Events have been looked at from a quantitative, cost-benefit point of view, which makes it possible to link them to the process of commodification. The trust which modern society places in such forecasts encourages the taking of risks which would otherwise not be taken. It is precisely in this context that I draw on John Maynard Keynes' concept of "animal spirits", to recall that social life in general (which includes economic life, to which Keynes was referring in particular) is not governed by strict principles of rationality, and we cannot therefore relegate to the background other existential and contextual areas of unpredictability and randomness. Secondly, I argue that the assessment of uncertainty has political and normative implications. I hold that uncertainty may make it possible to invoke precautionary (not just preventive) measures, and that alternative "contextualised" research strategies, open to a variety of points of view, are possible. As a final thought, I argue that the language of risk and its excessive application - riscophrenia - is generally laden with a type of ambiguity which tends not to emphasize society's current problems, and so facilitates the continuation rather than the questioning of our society's dominant technocratic and technological model.

\section{ThE UNAVOIDABLE NATURE OF UNGERTAINTY AND ITS GOMMODIFICATION}

In an essay published at a time when there was a boom in studies adopting the term "risk" as a key concept for examining modern-day society, which had been largely brought about by the translation into English of Ulrich Beck's Risk society (1992 [1986]), the Portuguese sociologist Hermínio Martins reminds us of the conceptual distinction between probabilistic risk and non-probabilistic uncertainty, formulated by Frank Knight and John Maynard Keynes in the 1920s, and he argues: "If we take seriously the predominantly economic terms in which risk is interpreted, the expression 'risk society' might suggest to us (more) a society which rationalizes technological dangers, like all others, by drawing up an ever increasing number of models of cardinal probability (...), rather than a society which suffers existential anxiety over its obligations to future generations" (2011 [1998], p. 196-7). As the author explains, the perplexity in this statement derives from a certain barely comprehensible mimicry on the part of sociologists who were theorizing about a fin de siècle situation, and the strong tendency in the economic mainstream to devalue uncertainty. The fact that the future was combined with the idea of probabilistic risk meant that traditional ideas of the social world as something radically uncertain and indeterminate were disregarded.

Before it expanded in macro-sociological terms, thanks to Beck and other writers who developed their theories around the notion of "reflexive modernization," the 
idea of risk had been used in "risk assessments" and "cost-benefit analyses" and widely applied by experts and regulators (mostly engineers, planners and economists) to the design of relatively structured mechanical systems such as nuclear and chemical plants, and aircraft and aerospace technologies (cf. Wynne, 1992). The work of those writers now extended the notion to the study of unstructured, disparate problems, from climate change to transnational terrorist networks. At the same time, the idea was appropriated by a broader range of actors concerned with the acceptance of risk and the perception of ambivalence and insecurity in connection with technical advances (cf. Strydom, 2002). Risk thus made a devastating entrance into the language of the academy, politics, the media and the public at large, with the result that many aspects of today's way of life and social organization came to be designated, described and analysed using the term "risk". A kind of riscophrenia arose, ${ }^{3}$ an excessive tendency or irresistible attraction to the probabilistic concept of risk, based on an image of the putative safety and control over the random and the contingent, which represents a culture which denies chance. Risk became a kind of totem deeply embedded in the logic of the advanced modern-day world, and gained traction in a large quantity and diversity of theoretical and empirical studies, specialised journals, academic courses, research centres, international conferences, etc.

A certain frenzy surrounding the notion of risk led to the erroneous redefinition, as risks, of some issues which are effectively uncertainties, as we shall see below. This redefinition came wrapped in a cloak of ambiguity, in that the language of risk was used to describe problems which go beyond the usual definition of risk - as the likelihood of the occurrence of a certain damaging event multiplied by the intensity of harm caused by that damage. The very theory of "the risk society", mentioned earlier, contains an echo of the idea of uncertainty, but does so in the name of risk. In assuming this dominant role, risk glosses over and relegates uncertainty, and makes it unthinkable. Restoring the conceptual distinction between risk and uncertainty advanced by Frank H. Knight (1921) and John Maynard Keynes (1921; 1954 [1936]), in the tense context of the post-World War One world, enables us to see how misguided that tendency was. While it has been widely developed elsewhere (cf. Reddy, 1996; Martins, 2011 [1998]; Dupuy, 2002), ${ }^{4}$ it is important to mention succinctly that for those economist-philosophers, a context of risk is that which can be assessed and calculated in terms of its numerical probabilities, unlike uncertainty, which cannot be assessed by

3 This is a term which picks up on the celebrated concept of "quantophrenia" developed by Pitirim Sorokim (1956), a sociologist who in the 195 os denounced American sociology's 'cult' of wanting to transform everything into numbers through the introduction of quantitative methods and the logic of measurable events.

4 For a broader perspective on uncertatinty in economic theory, see Greer (2000); Moureau and Rivaud-Danset $(2004)$. 
measurable calculation. They shared the idea that market actors were confronted with an irreducible uncertainty which cannot be eliminated by an increase in the amount of information or a greater application of science, because it is part of the ontologically contingent, true and unpredictable nature of things (cf. Martins, 2011 [1998], p. 198).5 As a "radically distinct notion", in the words of Bernstein (1998 [1996], p. 2153o), uncertainty was in no way suited to the dominant patterns of thought of the time which sought to make economics "scientific" by studying how this science would behave if individuals were completely rational and conducted themselves only on economic grounds. While classical theory was right in its analysis of many problems, it tended to overestimate the stability of the market economy, including those areas in which results were inevitably uncertain and for which their could not be deterministic or causal laws governing economic life and decision-making. In order to emphasize the irreducible uncertainty and volatility of expectations, particularly expectations about others' expectations (largely indeterminate), Keynes introduced the notion of "animal spirits", an idea which was not received with much enthusiasm at the time. ${ }^{6}$ "Animal spirits seemed a diabolus ex machina - an artificial element introduced to make the story come out wrong", as economist Roger Koppl explains (1991, p. 204). However, for Keynes, "animal spirits"7 (or "states of mind", $\mathbf{8}$ instincts, beliefs, compulsions, etc.) produced "a spontaneous urge to action rather than inaction, and not as the outcome of a weighted average of quantitative benefits multiplied by quantitative probabilities" (Keynes, 1954 [1936], p. 161). The emphasis he gave to "characteristics of human nature" was justified by the argument that "a large proportion of our positive activities depend on spontaneous optimism rather than on a mathematical expectation" (ibid.). It should be noted, as Robert Skidelsky, the best-known biographer of Keynes, explains, that Keynesian uncertainty is associated with negative and positive

5 In many books and articles, the priority for the distinction between risk and uncertainty is assigned to Knight's Risk, uncertainty and profit, published in 1921, and this pioneering exploration had been followed by Keynes' masterwork, The general theory of employment, interest and money, published in 1936. However, as Hermínio Martins explains, the idea of uncertainty was also set out in Keynes' A treatise on probability, also published in 1921. He used the term "subjective risk", which covers a kind of non-calculable and non-insurance risk, instead of "uncertainty" (Martins, 2011 [1998], p. 197). There is also some controversy as to who is the author of the distinction. Reddy points out that it was first formulated by J.H.von Thunen, in mid-nineteenth century (Reddy, 1996, p. 226-7).

6 The roots of the concept are to be found in the physiology of the Greek physicians of classical antiquity. Stated succintly, its etymological origin goes back to Galen (ca. 130-200), for whom animal spirits explained sensation and movement. Another important figure who used the term was René Descartes, in the seventeenth century. In his theory, individuals may act independently of reason, or even in opposition to it. Body movements are caused by movements of animal spirits, but these may be affected by the emotions, the mind or the soul (Koppl, 1991).

7 In A Treatise on probability, Keynes speaks of "whim" (or "caprice"), which later became "animal spirits" in The general theory of employment, interest and money (cf. Skidelsky, 2010 [2009], p. 128)

8 Some Portuguese economists prefer the term "states of mind" (Alexandre et al., 2009). 
beliefs about the future. None of these can be properly explained because they are subject to unexpected changes. In Skidelsky's interpretation of Keynes' thought, when we have no way of knowing what will happen in the future, it is rational - and above all reasonable - to act in accordance with expectations deriving from convention, basic principles, traditions and habits (2010 [2009], p. 135).

Recognition of uncertainty in general, and the idea that the behaviour of economic actors is shaped by factors other than the purely rational and cognitive, has gained some new life in economic theory in recent years and was indeed the grounds for awarding the Nobel Prize for Economics to Georges Akerlof, Michael Spence and Joseph Stiglitz (in 2001) and Daniel Kahneman (in 2002). That recognition also occurs with the resurgence of the Keynesian expression "animal spirits" in the recent context of the depression which followed the banking and financial crisis which erupted in the US in 2008 and had repercussions in Europe. ${ }^{9}$ The failure to foresee the crisis in the financial markets, which following an explosion of credit led to their asphyxiation, is due, according to some, to the devaluation of the idea of "animal spirits" in conventional macro-economic theory (Akerlof and Shiller, 2010 [2009]) or, similarly, to "the inability of the economy to take uncertainty seriously, camouflaging that negligence with sophisticated mathematical formulae" (Skidelsky, 2010 [2009], p. 252).

Sociology, with its focus on collective action, may help with "endogenizing 'animal spirits" in economic analyses, as argued by Paul DiMaggio. Three reasons may be pointed out. First, expectations regarding uncertainty are social constructions, in that they are an attribute of the social system and not of isolated individuals. Beyond understanding whether investors are rational, it is important to ask how rational they are as a group. Secondly, expectations, decisions and economic outcomes are all interdependent and, from this point of view, each decision-maker has to take into account the likely decisions of others. Finally, market actors are dealing with a dual uncertainty: uncertainty about the future state of the world, and uncertainty about the beliefs of other investors about the future state of the world (DiMaggio, 2002, p. 84,-5).

Looking at the most serious environmental problems of the twenty-first century through the prism of "animal spirits", as suggested in this article, is above all an exercise which shows that unpredictability and uncertainties are constituent elements of human existence and social life, even though this approach may be a daring one in that it relies on a broader understanding of the concept. In other words, uncertainties do not simply derive from our epistemological ignorance, rather they are inherent in the natural world and in social and institutional behaviour. I use "uncertainties" in the

9 The context in which Keynes popularized the expression was also one of crisis. The general theory of employment, interest and money was published following the Great Depression of 1929. 
plural because, rather than restricting uncertainty to its epistemic aspect (when we know what the most important parameters of the system are, but not its probability distributions, because our scientific knowledge is incomplete), we need to acknowledge other types of uncertainty which tend to be subsumed into the concept of risk, and complement that analysis using sociological variables. Brian Wynne, for example, offers a typology which, in addition to risk and epistemic uncertainty, includes ignorance and indeterminacy. Ignorance is often not recognized and reflects a series of uncertainties which remain invisible; indeterminacy harks back to the idea of an explanatory receptiveness arising from the contingencies inherent in social and institutional behaviour (cf. Wynne, 1992, p. 114-9; developed farther in Jerónimo, 2010). In our view, the notion of "animal spirits" touches on the idea of indeterminacy, given that both are opposed to the reductionist vision of social life which is governed only by strict rationality. To the same end, it might also be possible to draw on theories which other notable figures in the social sciences have developed, but this is not the place to pursue those: Vilfredo Pareto's "non-logic actions" and "derivations and residues", Thorstein Veblen “buoyancy”, Max Weber's "paradox of consequences”, Robert Merton's “unanticipated consequences".

Even when environmental problems undergo proper risk analysis assessment, conjoining the understanding of them with risk has the disadvantage that it neglects their complexity, the many layers involved, and significant political, psycho-social and ethical aspects. Such analyses often go beyond the language of probabilistic risk and do describe uncertainties, but these are designated epistemic uncertainties, and thus "enshrine the notion that the inadequate control of environmental risks is due only to inadequate scientific knowledge, and exclusive attention is focused on intensifying that knowledge, to render it more precise" (Wynne, 1992, p. 118, original emphasis). Playing on words, it is thus assumed that the "absence of evidence of damage" is equivalent to "evidence of the absence of damage". This way, the lack of conclusive empirical evidence of the harmfulness of a given phenomenon tends to be interpreted in a positive fashion, and this produces a false equivalence of epistemic uncertainty and ignorance with absence of risk. In actual fact, however, these are events for which there is no basis on which to assess probabilities, nor is it possible to know the complex and intricate set of potential consequences and networked interconnections. They embody "severe uncertainties", in the sense that their impact, if they occur, extends over a "constellation of seven predicates", as listed by Martins (2011 [1998], p. 211): they are unforeseeable, cumulative, profound, long, invisible, latent and irreversible.

The systematic association of environmental problems with the concept of risk is well illustrated in the vast panoply of forecasting instruments, such as modelling projections, matrixes, impact chains and projections of different future scenarios. 
Possible futures are advanced, possible disastrous events are projected, but the probability that any one of them will occur is neglected, as is the possibility that something never even imagined may happen as a result of the inherent randomness of the natural world and the contingencies involved in social and institutional behaviour. Moreover, based on those instruments, certain events may surprisingly become part of a logic of financialization. Climate insurance is an example: this includes "weather derivatives", "environmental mortgages", "forest-backed securities", "wetlands compensation instruments" and "catastrophe bonds" or "cat bonds". ${ }^{10}$ The latter, for example, were set up in the 1990s, promoted by the OECD and the World Bank itself, and have attracted increasing numbers of investors. The interest in them derives from the particular circumstance that they are not related to State-issued debt or to general trends in world markets, but rather to the possible damage and loss caused by natural disasters (e.g. hurricanes, earthquakes, floods, typhoons, thunderstorms, ice storms, largescale fires) in densely populated areas. Their aim is to spread the natural risks over space and time. States transfer to speculative instruments costs which they would, in the event of a tragedy, have to deal with by raising taxes and by recourse to the principle of national solidarity. And the financial modelling agencies incorporate nature into their mathematical models: "In accordance with variables such as wind speed, size of cyclones, temperatures and physical characteristics of the area in question (building materials, type of terrain, population), they assess the cost of a catastrophe, and the extent of the claims that the insurance companies will pay out. And, consequently, they determine the price of the cat bond" (Keucheyan, 2014, p. 35).

What we are witnessing here is a process of "commodification of contingency" or the use of risk as "a calculation of exposure to contingency" (Dillon, 2008). This process is extending to all the areas within reach of technoscience, from life forms to cyberspace. For example, the commodification of the biological world, made possible by the convergence of biological advances and the market, is creating a "global capitalist bioeconomy", which is driving "a market in biotechnological futures" or a "market in all biotechnological possibilities”, in the language of José Luís Garcia (2006). In this domain, life itself becomes an economic good, over which the large corporations

10 The Carbon Market (in other words, the market for the purchase and sale of licences to emit carbon dioxide and carbon credits), which was implemented with the Kyoto Protocol with the aim of reducing greenhouse gases, also follows the logic of financial markets and stock exchanges.

11 This same author recounts the recent discussion over creating a derivative linked to the disappearance of species ("species swap"). Under this scheme, firms which help to preserve biodiversity would see their profits increase. "Let us imagine that the state of Florida signs a species swap contract with a firm, based on a variety of turtle under threat which lives in the vicinity of the contracting state. If the number of turtle specimens increases as a result of the firm's efforts, the state will pay it interest; but if the turtles become scarce, or extinct, the firm must pay the state, so that it may embark on an operation to save them" (Keucheyan, 2014: 36). 
claim ownership, patent and exploitation rights, and which feeds future expectations forecast as being plausible. This logic of commodification reminds us of the oxymoron by which "cat bonds" are known: "Act of God bonds". They may well be acts of God, even though God clearly does not play the stock market.

It is a well-known fact that the development of science increased the range of predictable events and provided a greater sense of security, as far as, for example, the forecasting of certain natural disasters is concerned, but the order and direction of the world continue to resemble a wheel of fortune, profoundly affected by ontological indeterminacies. Recognition of the limits of our ability to imagine possible future events, of general ignorance of the parameters of a complex world, of the possibility of "surprises" brought about by technological development itself, and knowing that none of these items can be grasped by probabilities, makes it difficult to accept the expression "risk society". In this context, Martins argues that modern-day industrial societies should be designated "uncertainty societies" or "random societies" or even "democracies of uncertainty", given the importance of lay participation in issues which affect everyone and in relation to which there are uncertainties of all sorts (Martins, 2011 [1998], p. 203). Undoubtedly, such a designation does not mean that uncertainty can be used as a unified organizing principle for current economic and social circumstances. The same is true of risk. As Ramón Ramos (2004) explains, so-called risk societies contain uncertainties and uncertainty societies contain risks. Uncertainty is one of the faces of the risk society: it is glimpsed, but not admitted.

\section{Think UNGERTAINTY, AGT PREGAUTIOUSLY}

Living and acting in a world which aspires to control randomness but in which uncertainties impose constraints on our ability to carry out calculations and forecasts about the future leads us to dive into the unknown, in some areas. In markets, where epistemological and ontological impossibility prevent reliable estimates of the future results of investment from being made, economic actors end up behaving under the aegis of those animal spirits, as if they had well-founded and complete calculations and probabilities. They have confidence, and that very confidence is a risk response which seeks to avoid or escape from other risks. Like economic actors, political decisionmakers and experts who address complex environmental issues, and are under pressure to provide thoroughly black-or-white responses, tend to act as if they had absolutely solid foundations on which to provide them. They assume that with appropriate instruments and regulatory measures, risks can be assessed and above all managed and controlled. 
The decision as to whether such problems, which involve wide-ranging and unpredictable adverse effects, are analysed in terms of risk or in terms of uncertainty is not a neutral choice as far as its political implications are concerned. Elsewhere (Jerónimo, 2010) I have argued that risk is linked to a logic of prevention, while uncertainty is tied to the precautionary principle. These linkages are enshrined in international documents, like the two volumes of the European Environment Agency on case studies of technologies having adverse consequences but whose warning signs were ignored (EEA, 2001; 2013). While prevention generally leads to a process of mitigation, negotiation and acceptance of risks, precaution demands that we safeguard against damage whose level of danger is unknown, and may even lead to the refusal to take certain techno-economic decisions and actions.

Prevention and precaution both represent a prudent attitude in the face of the uncertain, but we may add foresight (prévoyance), along the lines suggested by François Ewald (1997). In this philosopher-jurist's interpretation, such attitudes developed and were appreciated in the West in three different historical periods. Foresight characterises the nineteenth century when prudence is envisaged at the individual level on the basis of responsibility and blame. Damage resulting from human error implies the right of redress; damage which is random, or the work of destiny, is seen in a fatalistic way. The twentieth century replaced foresight with prevention, and prudence came to be seen from the point of view of insurance and compensation. The random ceased to be seen as something fortuitous and became something identifiable, assessable and predictable. This is a rational attitude which relies on and trusts science and experts to render problems objective and measurable. It thus presupposes the notion of risk, inviting us to reduce uncertainty to risk and to mitigate the likelihood of its occurrence. In the transition from the nineteenth to the twentieth century a new attitude to prudence emerged, precaution. This deals with non-measurable risks and warns of the possibility of the occurrence of the worst-case scenario. Precaution is not tied to an individualist ontology as foresight is; it looks at the dangers which may threaten the whole of humanity, even if this is on a hypothetical level. Although precaution does not rule out the possibility of compensation for threats which have direct consequences for individuals, it describes a world in which, in principle, compensation makes no sense because the threats involved have irreversible consequences.

Generally speaking, the logic of prevention and risk have tended to dominate, although many recent disasters show the limits of both of them. The possibility that the disasters which affected New Orleans in 2005 and the area of Fukushima in Japan in 2011 might occur was well documented, and indeed even lead to some mitigatory and preventive action. However, those actions took place in a context which not only devalued radical uncertainty, but even risk itself, thus leaving room for "business as 
usual". It is a well-known fact that the severity of consequences depends not only on how strong the biophysical danger is but also on the vulnerability of things built by human communities (cf. Murphy, 2012). Strictly speaking, moreover, the memory of this kind of tragedy persists more strongly on account of the short-term and potentially long-term damage inflicted on human communities rather than on account of the magnitude and strength of the elements of nature. In the case of hurricane Katrina, which swept through New Orleans, Freudenburg and colaborators (2009) show how the disaster was magnified, in large measure, by human decisions and actions taken in the name of economic growth (which they call the "growth machine") which shaped the landscape over time, allegedly "improving it" but, at the same time, making it more vulnerable to the effects of a natural disaster. This story follows a common pattern; "it is not one of nature striking humans. It is the story about humans striking nature-and then enduring the tragic consequences" (Freudenburg et al., 2009, p. 170). Likewise the tsunami which invaded the land on the east coast of Japan, following a violent earthquake, took no heed of any of the preventive and protective measures against tsunamis at the Fukushima nuclear plant, provoking fires and explosions in several reactors, and the uncontrolled release of radioactive gases (cf. Garcia \& Jerónimo, 2013).

Prevention, when it derives from risk analyses which conclude that the risks of a given unit of technical infrastructure or of environmental problems are acceptable and that nothing is without risk, is based on an optimistic principle that no problem will arise from technological practices and systems for which we cannot find a technical solution in the future. Martins labels this principle, ironically, the "Axiom of Panglossian Existence", in which "there are always technological solutions to the problems engendered by technology" and that "these solutions will appear in time or will emerge within a timescale which is sufficient to prevent the worst disasters" (2011 [1997-1998], p. 176, original emphasis). ${ }^{12}$ In other words, current or future technology, on its own and without the need for a deeper analysis of causes, a more friendly posture towards the environment or the creation of low-impact technologies, will resolve the problems created by prior technologies. Note that I do not claim here to deny the importance of the technology factor nor to argue that the technological means is not sometimes necessary or that it does not solve many problems effectively. What is required, rather, is to recognize that technology is a contingent factor in a world in which the damage inflicted on the ecosystem is closely tied to our models of economic and industrial development, to guidelines for scientific research and technological innovation and also to the unforeseeable potentialities of technologies.

12 Agood critical analysis of this endless cycle of problems-solutions-problems, in connection with chemical products, is to be found in Colborn; Dumanoski and Myers (1996). 
Although it is true that the great panoply of risk analyses (e.g. risk assessment, cost-benefit analysis, environmental impact assessments, environmental audits, etc.) are based on reliable empirical evidence, that is not the same thing as stating that they represent an exhaustive analysis of the problems or that they do not favour certain values. As Hugh Lacey (2010) shows, values are precisely the factor which explains the emphasis on the exploitation of the possibilities of certain phenomena. Modern science is imbued with values (capital, market and military) which interact and mutually reinforce the "modern valuation of control". Associating things with these values and adopting on a massive scale research strategies which Lacey calls "materialist" and "decontextualized" means that events are reduced to their quantitative expressions and are taken out of their human, social and ecological contexts. In order to achieve a broader understanding of things, and to consider in all their complexity the consequences they may have on human experience and social organization, a great variety of strategies are required, including "contextualized" ones which make new approaches and partnerships possible. The logic of precaution and uncertainties seems to be closer to that broader approach, which takes into account different types of sensibility and is open to multiple points of view, as well as having a more participative focus which is not confined to expert technical analysis. There is no denying, however, that uncertainty may be "manipulated", in the sense of being exaggerated and magnified (in order to avoid taking decisions and to justify a moratorium) or indeed minimized (in order to encourage action).

As a civilization, we subject ourselves to several serious forms of danger, for guarding against which we do not have sufficient or secure foundations. An example of this is chemical substances which are launched into the atmosphere every day with no precise knowledge of their effects on public health or the environment. Expectations, on which decisions depend, are built up on the basis of risk analyses and on a determination of "acceptable" exposure. "It is hoped" that dangers below that threshold of acceptability will turn out to be truly harmless. This attitude, which in the final analysis is the permission of risk, fails to take into account our ignorance of potential adverse effects, and the indeterminacy of social behaviours, of technical systems and even of nature. The rationality of risk analyses collapses, because they conceive of things as physical entities which exist independently of the individuals and institutions which analyse and experience them (cf. Wynne, 1987). Many so-called serious risks have tended to be seen as "non-events" - "not just unfortunate, but uncommon, unexpected, unplanned, uncontrollable" (Hewitt apud Freundenburg et al., 2009, p. 8). This is important, at a time of increasing human influence over patterns which we previously called "natural". One of the assumptions of the notion of risk is its focus on human 
Risgophrenia AND “ANimAl SPIRIts": GLARIFying the NOTIONS OF RISK...

action, which means that neither the force of tragic natural events nor the indeterminacies of technical systems are taken into consideration - in other words, the open possibilities of technical objects (i.e. those which are not totally foreseeable or controllable). While it is true that many of the events taking place in the natural and social world bear the mark of human action, not all of them are provoked or attributable to it. "Are there still any natural disasters?", asks Jean-Pierre Dupuy (2006) - in other words, is there moral equivalence between a natural evil and an event provoked by man, a moral evil, such as for example the persistent ecological damage that is being done by man, or a terrorist attack? In this French philosopher's interpretation, it was the plan to control nature that put us in a position where there are apparently no more natural disasters. If "nature becomes (...) entirely that which we make of it, then clearly there is nothing external, and everything in the world will sooner or later reflect that which men did or did not do, did or did not desire or, by contrast, that which they neglected" (2006, p. 1188). But to posit an anthropological definition of disaster does not mean ruling out its natural aspects. Although many ecological disasters are a combination of natural and moral evil, it is crucial to make clear distinctions among them, in order to determine that which can be strictly put down to human responsibility, so that we may reverse those disasters through political action and thus not fall into despair, nor into an exaggerated constructivism in which every contingency or any aspect of externality is attributed to human action.

\section{RisK AS A DEVIGE FOR RATIFYING THE TEGHNO-SGIENTIFIG MODEL}

I suggest, as part of my critique, that the language of risk is to be interpreted as a device for rationalizing the features of the prevailing techno-structure and technological-scientific model in our society, and thus gives rise to evaluation practices which hardly go further than ratifying the status quo. Risk makes it possible to extend the effective application of the technologies and the techno-science responsible for the problems which are subsequently designated as risks. It does not question their foundational assumptions or the various tendencies embedded in the instrumental point of view with which modernity is strongly impregnated. It not only adjusts itself to the model which generates the problems, it also legitimises, justifies and ratifies them. Along these same lines of reasoning, Dominique Pestre asserts that risk "first of all masks the uncontrolled acceleration of a technical progress which it is left to innovators and experts to manage and to evaluate" (Pestre, 2013, p. 138-9). Even Beck, who, contrary to what I have argued, makes no distinction between risk and uncertainty, recognizes 
that there is a "cosmetics of risk", "not a preventive but a symbolic industry and policy of eliminating the increase in risks" (Beck, 1992 [1986], p. 57), and a coping with the symptoms rather than an addressing of the risks as causes or origins of the problems.

Under the aegis of the risk approach, events and their multiple complexities and opaque interactions are reduced to probabilities and to a value which, being scientifically acceptable, makes their acceptance by society legitimate. Historically this extending rather than questioning of certain prevailing attitudes in the technological and scientific system of production, by means of the language of risk, can be seen as embodying a history of "small disinhibitions", in which there is first a recognition of the dangers and secondly their normalization or acceptance through change in people's perceptions and behaviour. The expression comes from the historian of science JeanBaptiste Fressoz (2012) who, in an analysis of risk over the long term, shows how the history of modern Western society is not a history of unconscious change in its context, but rather one of successful construction of the devices which produced the disinhibitions of modernity and the climate of "happy apocalypse" in which we live. In the eighteenth and nineteenth centuries, when the idea of progress was still the prevailing matrix, modernization was already being discussed in terms of risks, uncertainties, the fallibility of science and man's responsibility for nature. The legitimisation of technological achievements takes place a posteriori, aided by a series of mechanisms such as regulations, safety standards, courts, administrative supervision, health surveys, and insurance.

A significant contributory factor in this process of "disinhibition" was the devaluation of radical uncertainty and its artificial conversion into merely epistemic uncertainties, which could be analysed using quantitative methods, with the aim of achieving public credibility and acceptance. But sometimes not even epistemic uncertainty is acknowledged. This is the phenomenon which could be called "uncertainty intolerance". In recent research on the regulation of transgenics, or genetically modified organisms, Asselt and Vos (2008), the originators of the concept, conclude that in reports by both Monsanto and the GMO Panel of the European Food Safety Authority (EFSA), "uncertainties are not acknowledged, deemed irrelevant, or are simply evaded, instead of genuinely and systematically investigated" (2008, p. 284). In Monsanto's case, the intolerance can be observed not only in the manner in which it addresses the problem in its reports (carrying out "safety assessments" instead of "risk assessments," and thereby deliberately avoiding the language of uncertainty), but above all in the concealment of potentially damaging uncertainty data. According to data put forward by the authors, results on tests of transgenic corn MON863 carried out on rats in December 2002 showed unexplained damage to the liver, but those results were deemed irrelevant by Monsanto, and were not included in the assessment report published in 
Risgophrenia AND “ANimAl SPIRIts": GLARIFying the NOTIONS OF RISK...

August of the following year. The EFSA on the other hand, which merely carries out meta-analysis of Monsanto's assessments, ends up corroborating that uncertaintydevaluing approach.

There are at least two areas where there are significant political and normative implications of whether radical uncertainty is weighed up and assessed or not. First, as Sanjay Reddy suggests, the subsumption of uncertainty in probabilistic risk "diverts attention from the truly radical and irreducible nature of our ignorance about the future world, which makes of it in turn an irreducibly political space" (1996, p. 24,2). When events which affect society as a whole and have potentially irreversible effects are being assessed, science should not be the only voice to be heard, nor should it be used as justification for obstructing other contributions and non-scientific criteria. In fact science, like other criteria, is necessarily partial, and that partiality increases the greater the uncertainty inherent in the context. That context, however, demands not that we do without science, but rather that science enter into a dialogue with other areas. Any retreat by the political and truly democratic elements in the face of technological solutions or economic and industrial interests will always have serious consequences for humanity as a whole.

Secondly, and given that, as we have seen above, uncertainty is inherent in the natural world and in human agency, and because however much knowledge increases, so too does ignorance, we should adopt a humble posture as far as the human ability to forecast and control the world is concerned. In many cases, the most we can hope to achieve is to improve our ability to explain (Pellizzoni, 2010). In addition, it cannot be denied that there is a small group of large corporations, industrial sectors and even stock markets all with strong economic interests. ${ }^{\mathbf{1 3}}$ Expectations of immediate returns, with costs stretching into the distant future, tend to encourage the acceptance of risks rather than precautionary policies (Murphy, 2012, p. 24). It is important to recall that there is a positive interpretation to the very concept of "animal spirits", which I have evoked here, in that it helps to avoid inaction in situations of grave uncertainty. However, that impulse to act - which may be creative and inventive and is therefore not to be related back to forecasts - is not a one-way street. Innovative action may be directed towards commercial projects which demand massive exploitation of natural resources, regardless of whether they produce potential inequalities, damage to the environment or threats to life on earth. Or it may be an opportunity for "reversing the socio-technical approach" (Gras, 2012, p. 181), and redirecting economies, national policies and (low-impact, reversible, recyclable) technological innovations towards equitable values, human well-being and maintaining equilibrium with nature, the animal world 
and future generations. In visions such as Sagoff's there is a belief that the proper compromise may lie somewhere between the reductionism of markets and the idealism of politics, between what we choose and what we are willing to pay as consumers (in markets, each individual follows his own idea of what "a good life" is) and that which we nevertheless value as citizens (as members of a community, we discuss and look for "a good society") (Sagoff, 1988). In any event, many environmental problems can and should be approached through changes in political and social attitudes and not merely through technologies, even alternative technologies, as is argued in much "green" capitalist theory.

Given the magnitude of current dilemmas, we need to pay close attention to the fact that political decision-making by governments is increasingly dominated by shortterm thinking, short-term calculation and short-term commitments, and to the hegemony of scientific operability, which assumes that problems which are ethical and political can be dealt with exclusively in technical terms. In relation to events which have arisen as a result of the environmental crisis and complex technological systems, we have every reason to believe that the excessive trust placed in merely technical solutions, the abstract, decontextualized strategies of techno-science and the strong influence of the financial and corporate world urgently need to be circumvented by the idea of reasonableness, in addition to rationality, that it should be acknowledged that uncertainties cannot be tamed, and that ethical values and political action should mediate techno-economic progress.A

\section{Helena Mateus Jerónimo}

School of Economics and Management and SOCIUS,

University of Lisbon, Portugal. jeronimo@iseg.ulisboa.pt

\section{REFERENGES}

Akerlof, G. A. \& Shiller, R. J. Espírito animal. Lisboa: Smartbook, 2010 [2009].

Alexandre, F. et al. A crise financeira internacional. Coimbra: Imprensa da Universidade de Coimbra, 2009. AsseLt, M. B. A. van \& Vos, E. Wrestling with uncertain risks: EU regulation of GMOs and the uncertainty paradox. Journal of Risk Research, 11, 2, p. 281-300, 2008.

BECK, U. Risk society: towards a new modernity. London: Sage, 1992 [1986].

Bernstein, P. L. Against the gods: the remarkable story of risk. New York: Wiley, 1996.

Conen, B. The triumph of numbers: how counting shaped modern life. New York/London: Norton, 2005 .

Colborn, T.; Dumanoski, D. \& Myers, J. P. Our stolen future: are we threatening our fertility, intelligence and survival? A scientific detective story. New York: Dutton, 1996.

Dillon, M. Underwriting security. Security Dialogue, 39, 2-3, p. 3०9-32, 2008. 
Risgophrenia ANd “ANimal SPIRIts”: GLARIFying the NOTIONS OF Risk...

DiMAGGio, P. Endogenizing 'animal spirits': toward a sociology of collective response to uncertainty and risk. In: Guillén, M. et al. (Ed.). The new economic sociology: developments in an emerging field. New York: Russell Sage Foundation, 2002. p. 79-100.

DupuY, J. P. Pour un catastrophisme éclairé: quand l’impossible est certain. Paris: Seuil. 2002. . Ainda há catástrofes naturais? Análise Social, 61, 181, p. 1181-93, 2006.

EEA. European Environment Agency. Late lessons from early warnings: the Precautionary Principle, 18962000. Luxembourg: Publications Office of the European Union, 2001.

European Environment Agency. Late lessons from early warnings: science, precaution, innovation. Luxembourg: Publications Office of the European Union, 2013.

Ewald, F. Le retour du malin génie: esquisse d'une philosophie de la précaution. In: Godard, O. (Org.). Le principe de précaution dans la conduite des affaires humaines. Paris: Maison des Sciences de l'Homme/ INRA, 1997.p. 99-126.

Freudenburg, W. R. et al. Catastrophe in the making: the engineering of Katrina and the disasters of tomorrow. Washington: Island Press. 2009.

Fressoz, J. B. L'apocalypse joyeuse: une historie du risque technologique. Paris: Seuil. 2012.

Garcì̀a, J. M. G. La diosa Fortuna: metamorfosis de una metáfora política. Madrid: Machado Libros, 2006.

Garcia, J. L. Biotecnologia e biocapitalismo global. Análise Social, 61, 181, p. 981-1009, 2006.

Garcia, J. L. \& Jerónimo, H. M. Fukushima: a tsunami of technological order. In: Jerónimo, H. M.; Garcia, J. L. \& Mitcham, C. (Ed.). Jacques Ellul and the technological society in the 21st century. Dordrecht: Springer, 2013. p. 129-44.

Godard, O. (Org.). Le principe de précaution dans la conduite des affaires humaines. Paris: Maison des Sciences de l'Homme/INRA, 1997.

Gras, A. A mega-máquina da globalização e do desenvolvimento insustentável: retornar à simplicidade. In: LÉna, P. \& Nascimento, E. P. (Org.). Enfrentando os limites do crescimento. Rio de Janeiro: Garamond, 2012. p. 171-83.

GREer, W. B. Ethics and uncertainty: the economics of J. M. Keynes and F. H. Knight. Cheltenham: Edward Elgar Publishing, 2000.

Guillén, M. et al. (Ed.). The new economic sociology: developments in an emerging field. New York: Russell Sage Foundation, 2002.

Hacking, I. The emergence of probability: a philosophical study of early ideas about probability. Cambridge: Cambridge University Press, 1975 .

The taming of chance. Cambridge: Cambridge University Press, 1990.

Jerónimo, H. M. Queimar a incerteza: poder e ambiente no conflito da co-incineração de resíduos industriais perigosos. Lisboa: Imprensa de Ciências Sociais, 2010.

Jerónimo, H. M.; Garcia, J. L. \& Mitcham, G. (Ed.). Jacques Ellul and the technological society in the 2ist century. Dordrecht: Springer, 2013.

Keucheyan, R. Quando as finanças se conectam com a natureza. Le Monde Diplomatique Brasil, março, 2014 , p. $34,-6$.

Keynes, J. M. A treatise of probability. London: Macmillan, 1921.

The general theory of employment, interest and money. London: Macmillan, 1954 [1936].

Knight, F. H. Risk, uncertainty, and profit. Boston: Houghton Mifflin, 1921.

Koppl, R. Retrospectives: animal spirits. Journal of Economic Perspectives, 5, 3, p. 203-10, 1991.

KrüGer, L. et al. (Ed.). The probabilistic revolution. Cambridge: The MIT Press, 1987. $2 \mathrm{v}$.

Lacey, H. Valores e atividade científica 2. São Paulo: Associação Filosófica Scientiae Studia/Editora 34, 2010.

Léna, P. \& Nascimento, E. P. (Org.). Enfrentando os limites do crescimento. Rio de Janeiro: Garamond, 2012. 
Luhmann, N. Risk: a sociological theory. Berlin/New York: Walter de Gruyter, 1993 [1991].

Luján, J. L. \& Echeverría, J. (Ed.). Gobernar los riesgos: ciencia y valores en la sociedad del riesgo. Madrid: Biblioteca Nueva/OEI, 2004.

Lupton, D. Risk. London/New York: Routledge, 1999.

Martínez, J. R. El riesgo como topía negativa: notas para una reflexión. In: Torre, R. R. \& Selgas, F. G. (Ed.). Globalización, riesgo, reflexividad: tres temas de la teoría social contemporánea. Madrid: CIS, 1999, p. 191-204.

Martins, H. Experimentum humanum: civilização tecnológica e condição humana. Lisboa: Relógio D’Água, 2011.

Measham, T. \& Lockie, S. (Ed.). Risk and social theory in environmental management. Collingwood: CSIRO Publishing, 2012.

Moureau, N. \& Rivaud-Danset, D. L'incertitude dans les théories économiques. Paris: La Découverte. 2004.

Murphy, R. Managing risk under uncertainty. In: Measham, T. \& Lockie, S. (Ed.). Risk and social theory in environmental management. Collingwood: CSIRO Publishing, 2012. p. 17-26.

Pellizzoni, L. Risk and responsibility in a manufactured world. Science and Engineering Ethics, 16, p. 463$78,2010$.

Pestre, D. À contre-science: politiques et savoirs des sociétés contemporaines. Paris: Seuil, 2013.

Porter, T. M. The rise of statistical thinking, 1820-1900. Princeton: Princeton University Press, 1986.

Ramos, R. De la sociedad del riesgo a la sociedad de la incertidumbre. In: LuJÁn, J. L. \& Echeverría, J. (Ed.). Gobernar los riesgos: ciencia y valores en la sociedad del riesgo. Madrid: Biblioteca Nueva/OEI, 2004. p. 35-50.

REDDY, S. G. Claims to expert knowledge and the subversion of democracy: the triumph of risk over uncertainty. Economy and Society, 25, 2, p. 222-54, 1996.

SAgoff, M. The economy of the earth: philosophy, law, and the environment. Cambridge: Cambridge University Press, 1988.

SkideLSKY, R. Keynes: o regresso do mestre. Alfragide: Texto Editores, 2010 [2009].

Sовокім, P. A. Fads and foibles in modern sociology and related sciences. Chicago: Henry Regnery, 1956.

Sтrудом, P. Risk, environment and society. Buckingham and Philadelphia: Open University Press, 2002.

Torre, R. R. \& Selgas, F. G. (Ed.). Globalización, riesgo, reflexividad: tres temas de la teoría social contemporánea. Madrid: CIS, 1999.

Wynne, B. Risk management and hazardous waste: implementation and the dialectics of credibility. Berlin/ New York: Springer-Verlag, 1987 .

. Uncertainty and environmental learning: reconceiving science and policy in the preventive paradigm. Global Environmental Change: Human and Policy Dimensions, 2, 2, p. 111-27, 1992. 